\title{
The Survey of Increasing Popularity of Watching Television Channels in Yangon Division
}

\author{
Khin Shin Thant", Thet Thet Aung, Myat Mon Khaing, Khin Lay Myint, Hlaing Htake Khaung Tin \\ Faculty of Information Science, University of Computer Studies, Hinthada, Myanmar.
}

How to cite this paper: Khin Shin Thant, Thet Thet Aung, Myat Mon Khaing, Khin Lay Myint, Hlaing Htake Khaung Tin. (2021) The Survey of Increasing Popularity of Watching Television Channels in Yangon Division. Advances in Computer and Communication, 2(1), 7-14.

DOI: $10.26855 /$ acc.2021.06.001

Received: April 15, 2021

Accepted: May 10, 2021

Published: June 4, 2021

*Corresponding author: Khin Shin Thant, Faculty of Information Science, University of Computer Studies, Hinthada, Myanmar.

Email: hlainghtakekhaungtin@gmail.com

\begin{abstract}
Before mobile phone, over 40 years ago, television service was introduced. In 2020, many Television Channels with many services are becoming popular in Myanmar. People in almost of states and divisions in Myanmar watch TV series, TV programme in their leisure time with their families. Rate of watching TV channels, TV series, TV programme increases more interesting than others. Especially, Myanmar series, Many Drop, the mask singer, Myanmar Idol, Korea Series, India Series, Philippine Series and Beauty programme, other entertainment programme, education programme, etc. The aim of this paper is to survey total population, female population and \%, male population and \%, the rate of watching TV of townships in Yangon division. This paper compares the total population and total population of watching TV viewers and shows the rate (\%) of the watching TV viewers in whole Yangon division.
\end{abstract}

\section{Keywords}

TV channels, Townships in Yangon, Survey, Schedules and Percentage of watching

\section{Introduction}

Under British colony, progress of Myanmar Television Broadcasting Industry Myanmar was from 1886-1948. In 1936, radio was first introduced by British to Myanmar. In 1948, Myanmar got independence from the British but the country is still struggling for a federal union since then until now. Since 1979, television service was first introduced in Yangon, Myanmar. At the beginning, MRTV was launched on 3/6/1980 and then steady television facility was firstly publically launched in 1981. Gradually, many channel lines are expanded for entertainments, for information, for education, for health, for sports, for religion. Only two main TV channels MRTV (State own) and MWD (Military own) were the main source of media and entertainment for Myanmar until 2010. Staring 2010, international community became more positive and welcoming the transformation of Myanmar's political system into its democratic transition. It was around the time of 2010, new investments came in including media, technology and telecommunications. New television channels such as DBV with support and technology from Norway, 5Movies with support from France. Gradually, Myanmar movie and film makers started to reach out and accept for collaboration with other Asian Movie industry. Now default channel lines become up to 20 lines in Myanmar television channels.

This paper includes survey of watching TV townships in Yangon, the highest population city, commercial city in Myanmar. It surveys people in each township in Yangon with population, female, male, number of availability of communication amenities television, their watching television rate (\%). 


\section{Related Work}

In 2016, Jinbao Song and Lunlun Huang analyzed the rank of transmission observing in public opinion investigation. Surveillance of radio and TV agendas is proposed to integrate with the system architecture and focus on the technical requirements and the broadcasting process. More effective information is disseminated through statistical study. It delivers data analysis for radio and TV public view analysis.

In 2019, Rizki Briandana and Mohammad Irfan showed that applied innovation has a positive effect on ratings and share. It is therefore a competitive strategy in the digital world for television broadcasting. In 2019, Rajat Das Gupta has shown a link between TV viewing frequency and obesity and obesity in women of childbearing age. This paper organized in five sections. In Session 3.1, there are many sets such as Set Top Box, PSI, Skynet to watch local channels and global channels in Myanmar. In some modernized LCD, LED sets, 21 channel lines are installed as default. In session 3.2, the broadcasted Myanmar series are listed. In Session 4, the most popular channels' schedules are described. In Session 5, the result of population watching TV channels are analyzed and compared with charts.

\section{Television Channels in Myanmar Series}

\subsection{Television Channels in Myanmar}

There are twenty TV channels in Myanmar. The following channels are shown in Myanmar.

\subsubsection{MRTV}

MRTV, Myanmar Radio and television is an independent TV channel that chiefly transmits local news. In 1936, radio was broadcasting in Burma during the British colonial era. Bama Athan's regular program was set up in 1946 February, the British recognized the Burmese Broadcasting Corporation (BBS), offering Burmese and local news and foreign news and music, broadcasting and broadcasting. Carry out information and school series and English news and melody series. In 1948, it was named "Myanmar Honor". In 1988, it was renamed Myanmar Radio. In anticipation of the presentation of Yangon City FM in 2001, BBS/Myanmar Radio was the single radio station in Myanmar until it launched Yangon City FM in 2001. For years, its main broadcaster was located on 426 Pyay Road in Kamaryut Township, Rangoon. Myanmar's Television Service began trial in Yangon in 1979. MRTV was broadcasting on 1980; it started broadcasting on 3 June. Normal TV service began in 1981 with the NTSC standard. In 2005, MRTV made sure 195 TV stations nationwide. Since late 2007, the central broadcasting place has moved to Nay Pyi Taw. Myanmar's Television Service began trial in Yangon in 1979. MRTV was released in 1980. It began on June 3, and regular television services were officially launched in 1981.

\subsubsection{Channel 7}

Channel 7 is a 24 hrs. free TV channel and transmissions acting plans. It is also track by Forever Group. In 2012, Forever Group Co. Ltd has launched its second free channel. Channel 7 is well identified for its plans intended at young societies and its new series, containing the newest and greatest new series today. In 2014, Channel 7 launched DVB-T2 and DTH systems with high definition quality that was able to negotiate.

\subsubsection{Channel K}

Channel $\mathrm{K}$ is a 24 hrs. (day and night) free-to-air TV entertaining channel and transmissions performing series. It is launched in February 2019. The purpose of this channel is to target the whole of Myanmar in general, and the age group of 18 to 38 in particular. Channel $\mathrm{K}$ has four main components of a program: business, the film, music and culture. The TV channel also has some of the most popular places in the entertainment industry. This channel's ambassadors are the biggest hip hop star, Sai Sai Kham Leng, Myanmar pop queen Ni NiKhin Zaw, rock queen Phyu Phyu Kyaw Thein, Cultural icon Phoe Chit, Movie star Pyae Ti Oo and big screen actress Soe Pyae Thazin.

\subsubsection{Channel 9}

Channel 9, a 24 hrs. (day and night) free-to-air TV channel, transmissions entertaining programs.

\subsubsection{MRTV4}

In May 2004, a fresh TV channel, MRTV4, was launched by Myanmar Radio and TV under the Ministry of Information for a two-hour program. MRTV4 is a 24 hrs. free TV channel that transmissions entertaining programs. The channel is jointly broadcast by MRTV and Forever Group from 7 am to 11 pm. In April 2009, MRTV4 aired 18 hrs a day. Since September 2010, MRTV4 has become a 24 hrs. free TV channel and is presently the supreme popular 
TV network in Myanmar.

\subsubsection{MWD}

Myawaddy (MWD), a 24 hrs. (day and night) free TV channel, transmits entertaining programs. Myawaddy is the 23rd Burmese-owned TV system grounded in Rangoon and Naypyidaw, MWD Shopping, MWD Music and various MWD Series TV programs.

\subsubsection{Fortune TV}

With Fortune TV, a digital free-to-air television channel that will launch in early 2019, the group has expanded into the broadcast entertainment industry. With the recent increase in the number of digital content providers in Myanmar, Fortune will provide quality information, FTA and OTT platforms. Fortune TV is ready to create a television media landscape and engage audiences across the country.

\subsubsection{MRTV entertainment}

MRTV Entertainment is a 24 hrs. (day and night) free television network with the sole purpose of entertaining the public. Broadcast by state-owned Myanmar Radio and Television (MRTV) in Nay Pyi Taw.

\subsubsection{Mizzima TV}

Mizzima TV is a free-to air channel that broadcasted from 7:30 AM to 11:30 PM.

\subsubsection{YTV}

YTV is the new channel to launch Free to Air with DVB-T2. The cooperation agreement between the Union of Myanmar is on 17 February 2018. September 22 on 2016, Myanmar Radio and Television filed an application for Expression of Interest (EOI) by submitting a formal tender to the EOI. 44. The application was submitted next to the RFP. May 11 MY MULTIMEDIA CO. Ltd. Young Investment Group Co., Ltd. Announced by Limited His television career is one of the top 10 mentioned earlier.

\subsubsection{DVB}

TV is a 24 hour free TV channel in Myanmar. DVB (Democratic Voice of Burma) is a non-profit Brumes media organization. Our goal is to reach the people of Myanmar: to provide impartial information; to promote understanding and cooperation between the Burma and ethnic groups; to promote free public opinion; human rights for the people of Burma. DVB was previously in Norway. Registered in Oslo and DVB Multimedia Group is now officially licensed in Myanmar.

\subsubsection{Plus}

The 5 Plus is a 24-hour free broadcaster that can easily find it on the TV with a built-in digital tuner. To view it, 5 networks from T2 set-top boxes; Available on MWD, MRTV T2 and 4TV. Currently, 5Plus stands available in India, India to get different feelings and knowledge, Korea, Philippines and Thailand series. In addition, the 5 Plus offers health, fitness and fitness options. It offers programs related to entertainment and social issues. 5 Plus provides information, Educate Perfect for entertaining and entertaining. It is a digital free-to-air TV channel that creates and distributes broadcast solutions (Free 24 hrs). Active 5 Plus is a free channel to Air TV by creating and distributing solutions.

\subsubsection{MahaBawdi}

MahaBawdi Channel is a free-to-air channel that broadcasted things related Buddhist.

\subsubsection{Hluttaw Channel}

Parliamentary Channel is free. The Hluttaw Line is the official TV channel of the Pyidaungsu Hluttaw.

\subsubsection{MWD Movie Chanel}

This channel is produced by military and broadcasts movies and movie series.

\subsubsection{MWD Documentary Channel}

MWD documentary channel is one produced by military.

\subsubsection{MRTV—Sport Channel}

This channel is a free TV channel and shows only local and international sport news, sport training programme, local and global sport matches. 


\subsubsection{For EDU Channel}

This channel is a free-to-air channel and broadcasts education programme, education news and education things.

\subsubsection{Readers channel}

Reader Channel is a 24 hrs. (day and night) free air channel. It is led by Forever Group. Field Information Program that helps readers promote public literacy. It is nationally accepted for any device that includes DTH Terrestrial and digital tuners.

\subsubsection{Myanmar National TV (MNTV)}

MNTV is a 24 hrs. (day and night) free newscaster that transmissions entertaining programs. MNTV is a popular free airline in Myanmar.

\subsection{Myanmar Series}

Television Series or movies series such as Korea movie series, Thai movie series, India movie series, Philippines movie series, Chinese movie series, etc. are broadcasted in these Channels. Among them, Myanmar TV Series are broadcasted in MRTV-4 Channel cooperated with Forever Group Co. Ltd. and these Myanmar TV Series are popular and increased rate of watching in Myanmar day by day. These are lists of Myanmar movie series.

1. The Sign of Love

2. Forever Mandalay

3. Wit Nyin Shite Than

4. A Mone Ma The

5. Bagan Myo Thu

6. Magical Village

7. The Missing Truth

8. A Yake

9. Hnin Si

10. I'm Mahaythi

11. The Seven Banknotes

12. Where There is Love

13. Chit Ya Par Thaw Nway

14. Tatiya Myaut Sone Mat

15. A Chit Phwae Lay Nyin

16. Legends of Warriors

17. Myetlone Mar Alwan Notekhan Mar Marna

18. Kya Naw A Mone Sone Kya Naw

19. G Hall Thu

20. It Was On Yesterday 2

21. Room Number?

22. Dark Castle

23. Tharmometer

24. Pann Nu Thwe

25. Honey Lake

26. Poison Blood

27. Track of Mind

28. Wit Nyin Shite Than

29. Land where love together meets

30. I Who I hate most

\section{TV Channels and Their Daily Schedules}

As the Myanmar Television channels are increasing popular and quality, movies series (Korean, Thailand, Philippines, India, Myanmar) are very increasing rate of watching in these channels. Among these channels, the most popular channels and their schedules are described in Figures (Figures 1-6). 


\section{Survey Results of Watching Television in Township of Yangon Division}

In Figure 7, total population, male population and percentage (\%), female population and percentage (\%), number of television, total population of watching television and percentage (\%) of 50 townships in Yangon Division are surveyed and analyzed. And 50 divisions are divided into 5 parts and each part including 10 townships are described and compared with charts as followed.

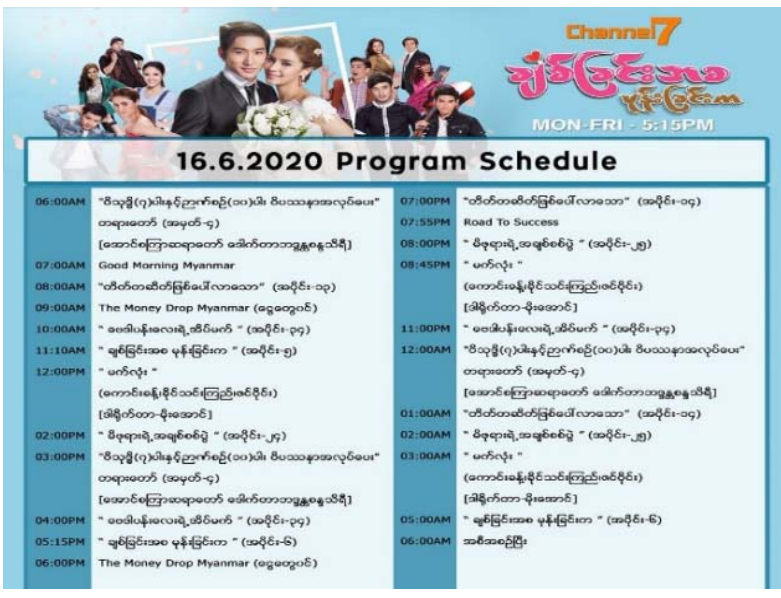

Figure 1. Channel 7’s program schedule.

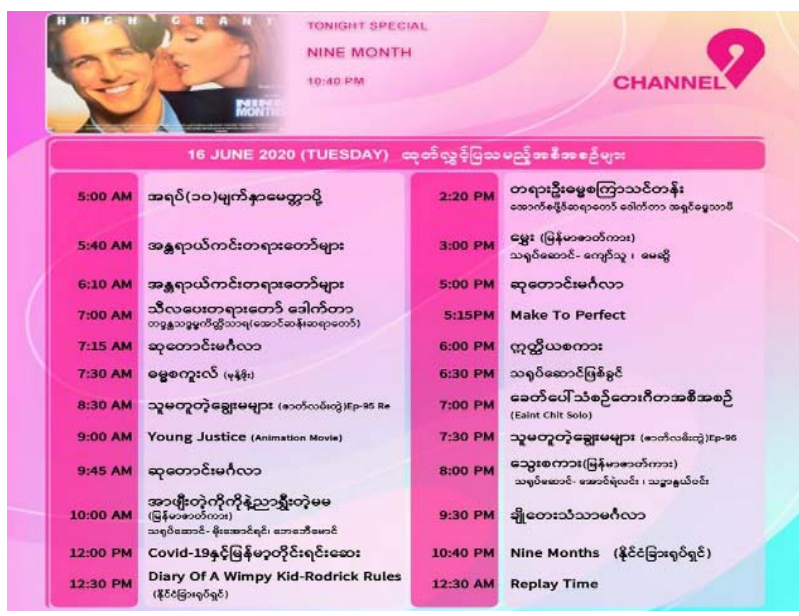

Figure 3. Channel 9's program schedule.

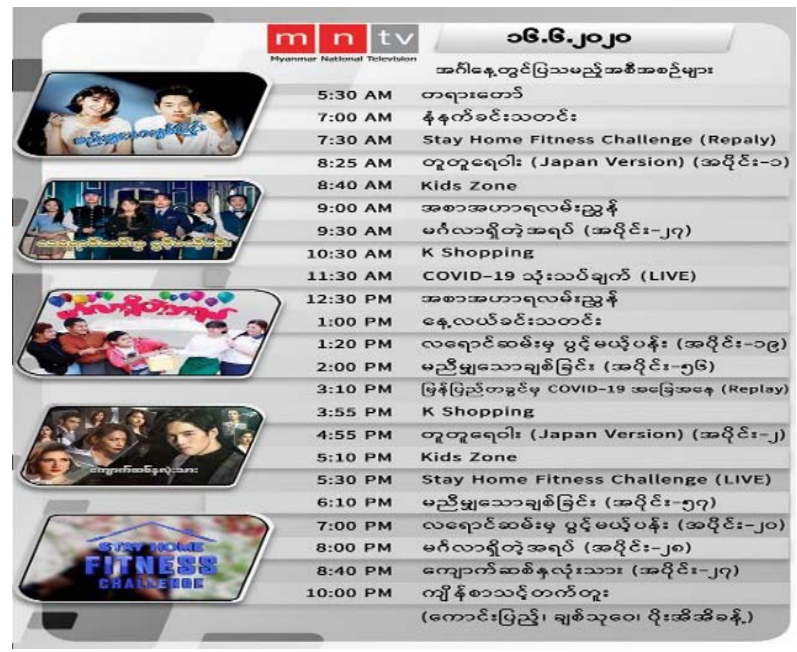

Figure 5. MNTV's program schedule.

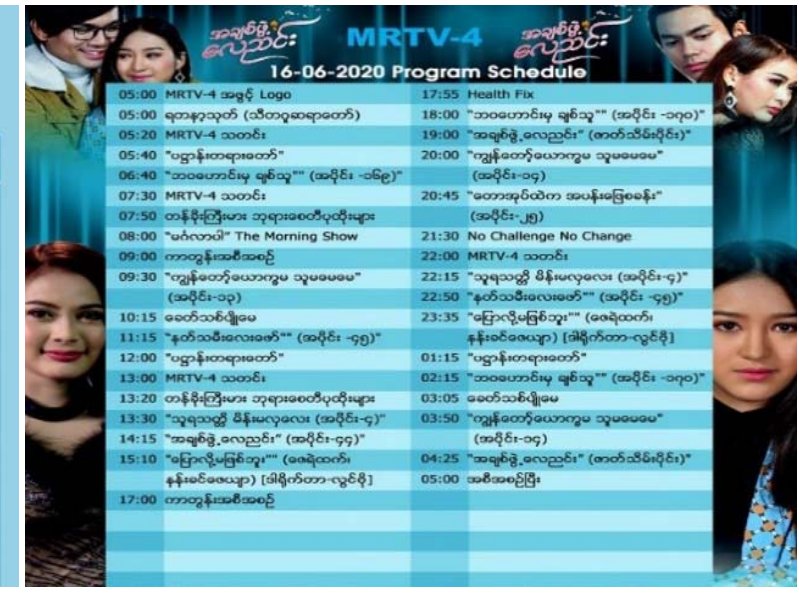

Figure 2. MRTV-4's program schedule.

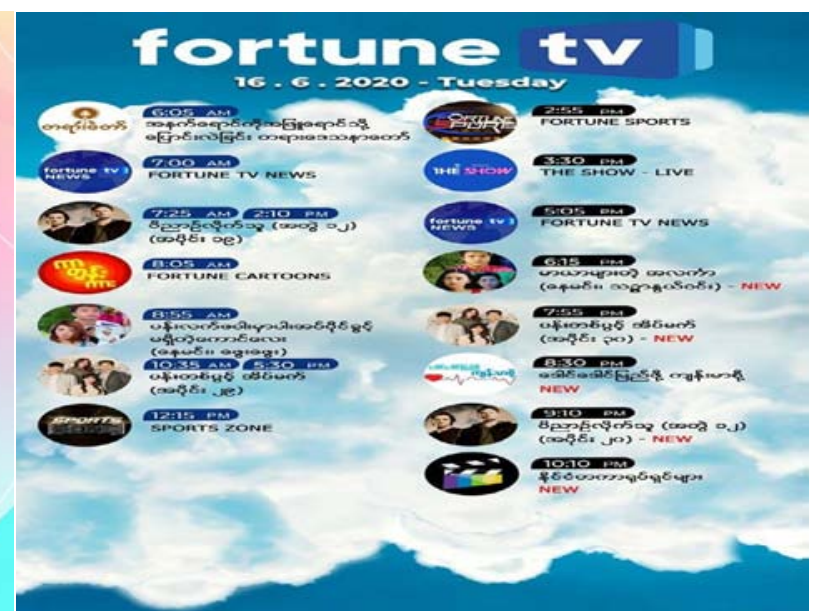

Figure 4. Fortune TV's program schedule.

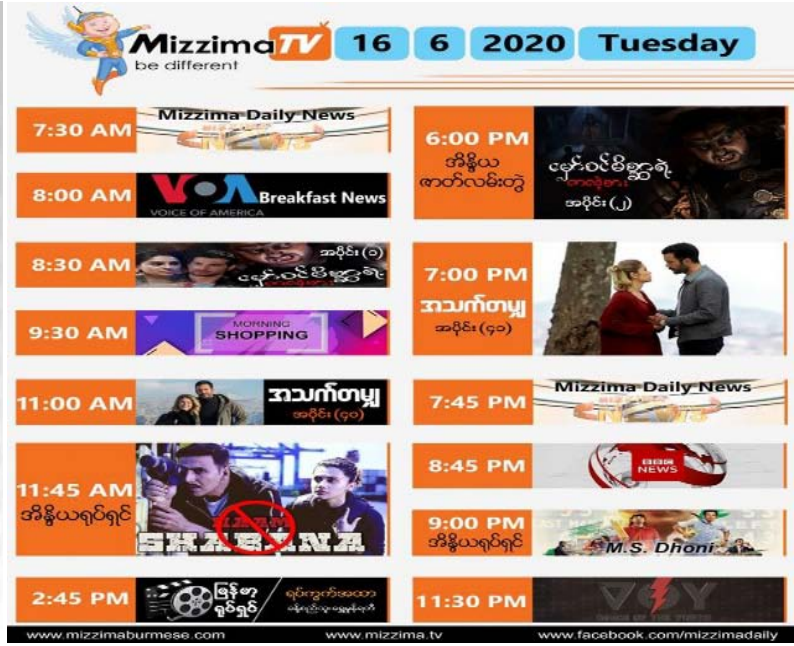

Figure 6. Mizzima TV's program schedule.

Advances in Computer and Communications 


\begin{tabular}{|c|c|c|c|c|c|c|c|}
\hline No & Temuship & $\begin{array}{c}\text { Total } \\
\text { Populati } \\
\text { on }\end{array}$ & Male & Female & $\begin{array}{c}\text { No of } \\
\text { Televisi } \\
\text { on }\end{array}$ & $9 \%$ & $\begin{array}{c}\text { Tocal of } \\
\text { Watching } \\
\text { TV }\end{array}$ \\
\hline 1 & Thakurata & 220,556 & $\begin{array}{l}107,290 \\
(48,690) \\
\end{array}$ & $\begin{array}{l}113,266 \\
(51.4 \%) \\
\end{array}$ & 39.125 & $\begin{array}{l}86 . \\
1 \\
\end{array}$ & 189898.716 \\
\hline 2 & Kungyangon & 111,632 & $\begin{array}{l}54,107 \\
(48.5 \%)\end{array}$ & $\begin{array}{l}57,525 \\
(51.5 \%)\end{array}$ & 10,921 & $\begin{array}{l}38 . \\
5\end{array}$ & 42978.32 \\
\hline 3 & KyiMyintNaing & 111,514 & $\begin{array}{l}52,627 \\
(47.206)\end{array}$ & $\begin{array}{l}58,857 \\
(52.8 \%)\end{array}$ & 18.208 & $\begin{array}{l}81 . \\
1\end{array}$ & 90437.854 \\
\hline 4 & Alon & 55,482 & $\begin{array}{l}25,551 \\
(46.199)\end{array}$ & $\begin{array}{l}29,931 \\
(53.946)\end{array}$ & 10.229 & $\begin{array}{l}93 . \\
5\end{array}$ & 51875.67 \\
\hline 5 & Tamowe & 165,313 & $\begin{array}{l}74,662 \\
(45.20) \\
\end{array}$ & $\begin{array}{l}90,651 \\
(54.8 \%) \\
\end{array}$ & 33.464 & $\begin{array}{l}94 . \\
6\end{array}$ & 156386.099 \\
\hline 6 & Drasoo Mrothit (s) & 371,646 & $\begin{array}{l}181,140 \\
(48.79) \\
\end{array}$ & $\begin{array}{l}190,506 \\
(51.3 \%) \\
\end{array}$ & 00.271 & $\begin{array}{l}78 . \\
3 \\
\end{array}$ & 290998.818 \\
\hline 7 & Dasoes Myothit (n) & 203,948 & $\begin{array}{l}96,388 \\
(47.309) \\
\end{array}$ & $\begin{array}{l}107,560 \\
(52.78) \\
\end{array}$ & 37,961 & $\begin{array}{l}88 . \\
9\end{array}$ & 181.309 .772 \\
\hline 8 & Dasoe Myrthit (e) & 165,628 & $\begin{array}{l}80,861 \\
(48.8 \%) \\
\end{array}$ & $\begin{array}{l}84,767 \\
(51.28)\end{array}$ & 25.292 & $\begin{array}{l}74 . \\
6\end{array}$ & 123558.488 \\
\hline 9 & Dascon & 25,082 & $\begin{array}{l}11,846 \\
(47.28)\end{array}$ & $\begin{array}{l}13,236 \\
(52.8 \%)\end{array}$ & 4.438 & $\begin{array}{l}96 . \\
3\end{array}$ & 24153.966 \\
\hline 10 & $\begin{array}{l}\text { Dagoe Myothit } \\
\text { (Seikkan) }\end{array}$ & 167,448 & $\begin{array}{l}82,697 \\
(49,49)\end{array}$ & $\begin{array}{l}84,751 \\
(50.65)\end{array}$ & 23.586 & $\begin{array}{l}62 . \\
2\end{array}$ & 104152.656 \\
\hline 11 & Hlinethaya & 687,867 & $\begin{array}{l}322,862 \\
(46.989) \\
\end{array}$ & $\begin{array}{l}365,005 \\
(53.18) \\
\end{array}$ & 93.222 & $\begin{array}{l}62 . \\
7\end{array}$ & 431292.6099 \\
\hline 12 & Scikkyi Khanarngto & 34,003 & $\begin{array}{l}17,068 \\
(30.209) \\
\end{array}$ & $\begin{array}{l}16,935 \\
(49.825) \\
\end{array}$ & 5.280 & $\begin{array}{l}68 . \\
3 \\
\end{array}$ & 23224.049 \\
\hline 13 & Thingangyun & 209,486 & $\begin{array}{l}98,698 \\
(47.1 \%) \\
\end{array}$ & $\begin{array}{l}110,788 \\
(52.945) \\
\end{array}$ & 38,352 & $\begin{array}{l}88 . \\
5 \\
\end{array}$ & 185395.11 \\
\hline 14 & Shue Pyi Thar & 343,526 & $\begin{array}{l}164,264 \\
(47.899) \\
\end{array}$ & $\begin{array}{l}179,262 \\
(52.2 \%) \\
\end{array}$ & 50.778 & $\begin{array}{l}68 . \\
8\end{array}$ & 236345.888 \\
\hline 15 & La Ma Taw & 47,160 & $\begin{array}{l}20,180 \\
(42.8 \%)\end{array}$ & $\begin{array}{l}26,980 \\
(57.2 \%)\end{array}$ & 8108 & $\begin{array}{l}94 . \\
3\end{array}$ & 44471.88 \\
\hline 16 & $\mathrm{BaHan}$ & 96,732 & $\begin{array}{l}45,518 \\
(47.1 \%) \\
\end{array}$ & $\begin{array}{l}51,214 \\
(52.9 \%)\end{array}$ & 16.412 & $\begin{array}{l}94 . \\
2\end{array}$ & 91121.544 \\
\hline 17 & $\begin{array}{l}\text { Mingala Taung } \\
\text { Nyunt }\end{array}$ & 1.32 .494 & $\begin{array}{l}62,530 \\
(47.20)\end{array}$ & $\begin{array}{l}69,964 \\
(52.8 \%)\end{array}$ & 23,847 & $\begin{array}{l}92 . \\
2\end{array}$ & 122159.468 \\
\hline 18 & Magalar Done & $3.31,586$ & $\begin{array}{l}158,259 \\
(47.796) \\
\end{array}$ & $\begin{array}{l}173,327 \\
(52.3 \mathrm{M}) \\
\end{array}$ & 54.116 & $\begin{array}{l}81 . \\
6 \\
\end{array}$ & 270574.176 \\
\hline 19 & San Chang & 99,619 & $\begin{array}{l}43,993 \\
(44.29) \\
\end{array}$ & $\begin{array}{l}55,626 \\
(55.825) \\
\end{array}$ & 19.630 & $\begin{array}{l}95 . \\
1 \\
\end{array}$ & 94737.669 \\
\hline 20 & Mew Be & 244,6007 & $\begin{array}{l}120,931 \\
(49,49)\end{array}$ & $\begin{array}{l}123,676 \\
(50.685)\end{array}$ & 36.079 & $\begin{array}{l}63 . \\
9\end{array}$ & 156303.873 \\
\hline
\end{tabular}

Figure 7. Population and total watching TV viewers of 20 townships in Yangon Division.

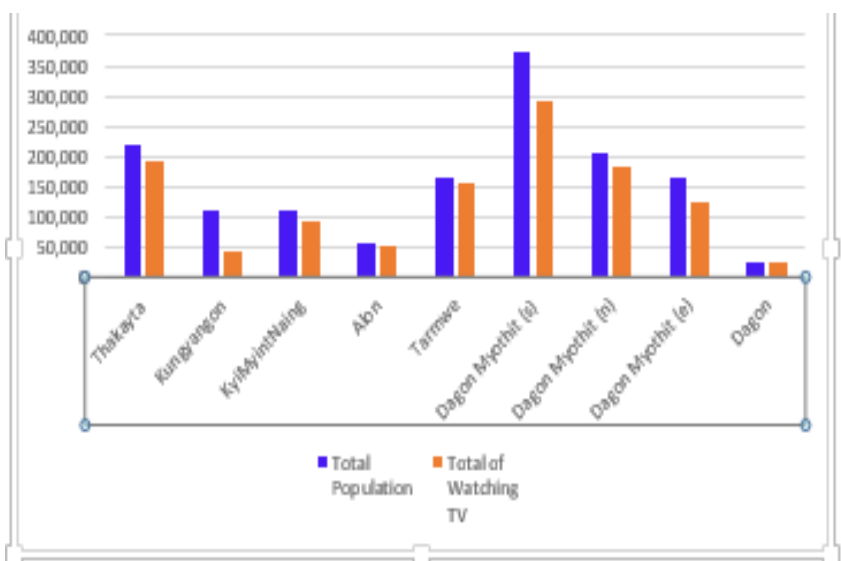

Figure 8. Total population and watching TV in 10 Divisions.

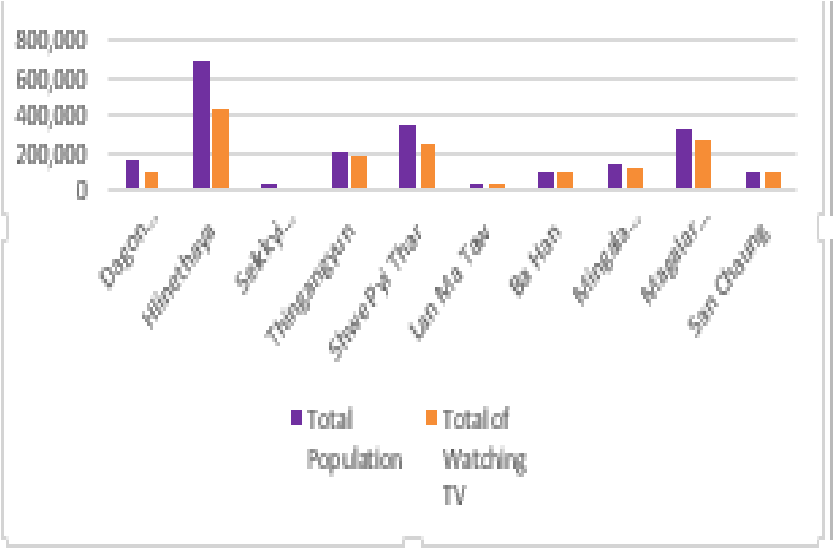

Figure 9. Total population and watching TV in 10 divisions.

In Figure 8, 10 Townships: Thakayta, Kungyangon, Kyi Myint Naing, Alon, Tarmwe, Dagon Myothit (sorth), Dagon Myothit (north), Dagon Myothit (east), Dagon, their total population and total of watching TV are compared in chart. In Figure 9, 10 townships: Dagon Myothit (Seikkan), Hlinethaya, SeikkyiKhanaungto, Thingangyun, 
ShwePyi Thar, Lan Ma Taw, Ba Han, Mingala Taung Nyunt, Magalar Done, San Chaung, their total population and total of watching TV are compared in chart.

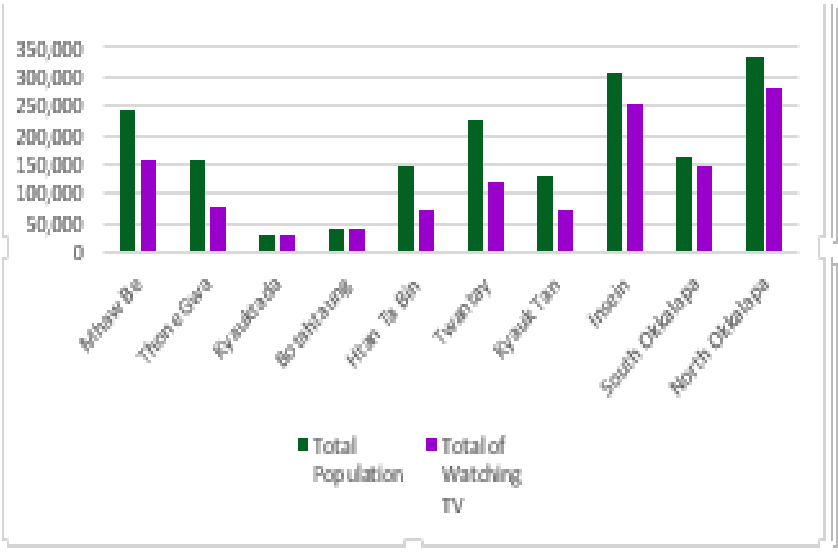

Figure 10. Total population and watching TV in 10 divisions.

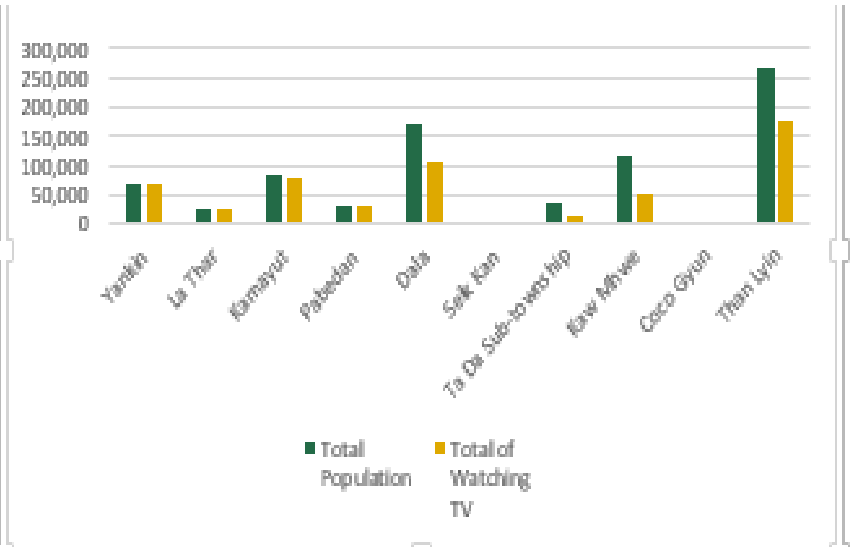

Figure 11. Total population and watching TV in 10 divisions.

In Figure 10, 10 townships: Mhaw Be, ThoneGwa, Kyauktada, Botahtaung, Htan Ta Bin, Twantay, Kyauk Tan, Insein, South Okkalapa, North Okkalapa, their total population and total of watching TV are compared in chart. In Figure 11, 10 townships: Yankin, La Thar, Kamayut, Pabedan, Dala, SeikKan, Ta Da Sub-township, Kaw Mhwe, Coco Gyun, Than Lyin, their total population and total of watching TV are compared in chart.

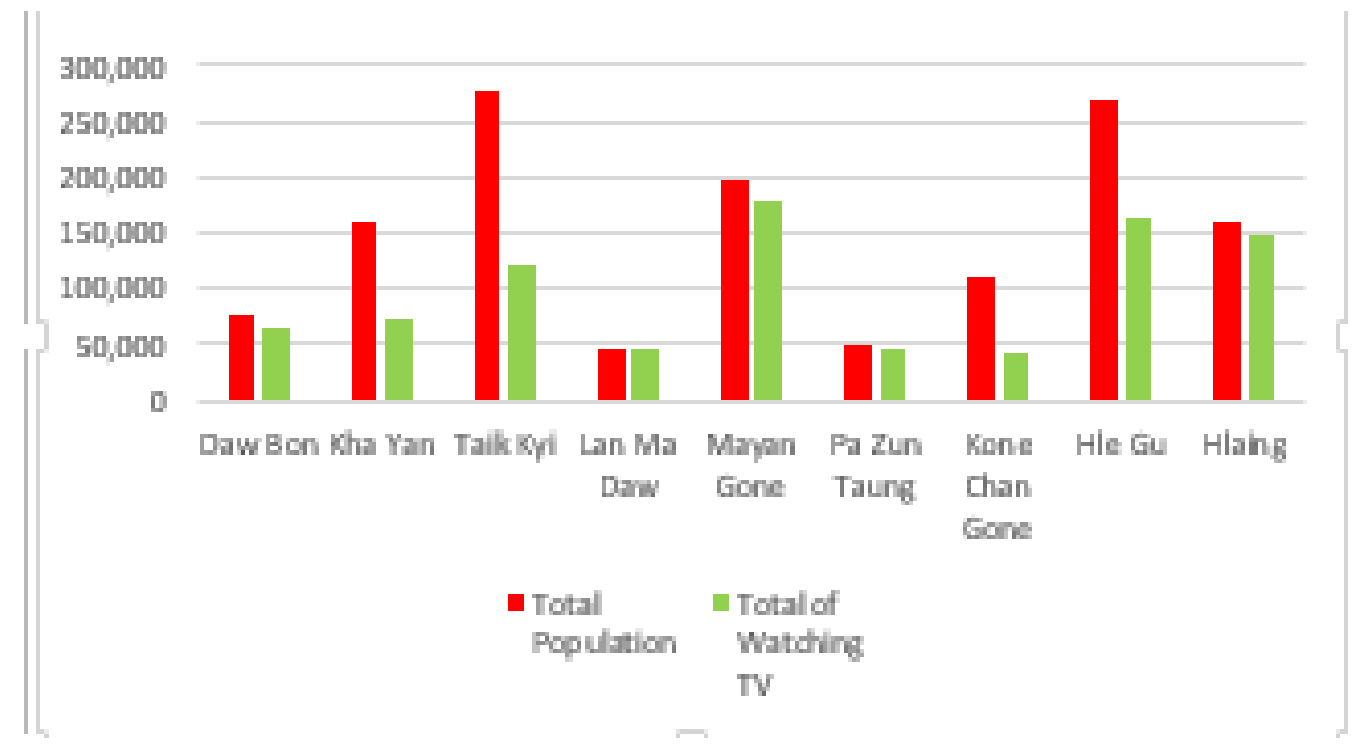

Figure 12. Total population and total of watching TV in 9 divisions.

In Figure 12, 9 townships: DawPon, Kha Yan, Taik Kyi, Lan Ma Daw, Mayan Gone, Pa ZunTaung, Kone Chan Gone, HleGu, Hlaing, their total population and total of watching TV are compared in chart.

Table 1. Result of watching TV in 49 townships in Yangon Divisions

\begin{tabular}{ccccc}
\hline & Total Population & Total of Watching Tv & Rate of Watching TV (\%) & Remark \\
\hline Yangon & $7,519,495$ & $5,441,735$ & $72 \%$ \\
Hlinethaya & 687,867 & 431,293 & $63 \%$ & \\
\hline
\end{tabular}

In Table 1, the total population of 49 townships in Yangon Division is 7,519,495 and total of watching TV is $5,441,735$. Therefore, the rate of watching TV is $72 \%$.

\section{Conclusion}

In conclusion, this paper surveys the default 21 channels displayed and broadcasted in the Myanmar and surveys 
each of 49 townships in Yangon division with their population, male population, female population, rate of watching TV channels and population of watching TV channels. And then, this paper evaluated total population of 49 townships, total population of watching TV channels and rate of watching TV (\%). Finally, this paper determines population of Hlinethaya is the highest of population 687,867 and total of watching TV is the highest 431,293 but the percentage is $63 \%$ medium. As the percentage, Tarmwe and San Chaung townships' percentage of watching TV are the highest $95 \%$. In the future work, female and male population of watching TV channels and \% in each township will be researched.

\section{Acknowledgements}

We would like to acknowledge all of our colleagues at University of Computer Studies, Hinthada for their care and help through our research effort. Big thanks a lot to our families for their help and support.

\section{References}

[1] JinBao Song, LunLun Huang. (2016). “Analysis and Implement of Broadcast Program Monitoring Data”, DOI: 10.1051, MATEC Web of Conferences, 2016.

[2] Anna Zongollowicz. (2017). "Viewersip \& Listening Survey Lashio \& North Okkalapa”, 2017.

[3] Rizki Briandana, Mohammad Irfan. (2019). "Broadcasting Management: The Strategy of Television Production Configuring for Sustainability in the Digital Era”, Vol-4, Issue-6, Nov-Dec 2019, ISSN: 2456-7620, DOI: 10.22161.

[4] Rajat Das Gupta, Ibrahim Hossain Sajal, Mehedi Hasan, Ipsita Sutradhar, Mohammad Rifat Haider, Malabika Sarker. (2019). "Frequency of television viewing and association with overweight and obesity among women of the reproductive age group in Myanmar: results from a nationwide cross-sectional survey”, doi: 10.1136, 2019.

[5] Myat Zaw Htwe. (2019). "Yangon University of Economics Master of Public Administration Programme”, 2019. 